\title{
Causal Relationship of Employee Loyalty \& Organizational Commitment Based On Satisfaction Model
}

\author{
Baraka Mboka Mwaitinda ${ }^{1}$, Pei Feng $\mathbf{H u}^{2}$ \\ ${ }^{1}$ School of Management Science \& MBA, North China University of water resources and electric power, Henan, China \\ ${ }^{2}$ School of Management Science \& MBA, North China University of water resources and electric power, Henan, China \\ DOI: 10.29322/IJSRP.10.03.2020.p9921 \\ http://dx.doi.org/10.29322/IJSRP.10.03.2020.p9921
}

\begin{abstract}
This research paper examines causal relationship and impacts of employee's loyalty \& organizational commitment in manufacturing industry of Tanzania. Research paper intends to find out the extent to which factors such as: job Security, Supervisor Support, Fringe Benefits, Team Work, Environment and Training affect the loyalty and commitment. To achieve the purpose, study uses quantitative approach by conducting a survey in manufacturing industry of Tanzania, (Corporate Sector). Slovin's formula will be used for sampling. Further SPSS will be used to analyze the 5 likert scale questionnaire for correlation and regression. The study finds causal relationship between Employees Loyalty and Organizational commitment. Factors that impact the loyalty of an employee in manufacturing industry are: Job Security, Supervisor support, Fringe benefits, teamwork, environment and training. Application of research is theoretical contribution towards manufacturing industry of Tanzania, as manager will be able to practically apply these factors positively and retain good employees in working-team. Research provides insights for Tanzanian Manufacturing industry on satisfying needs of the employees working in organization to attain higher commitment towards organizations and loyalty of employees that will improve production and sales of the corporations.
\end{abstract}

Index Terms- Job Security, Supervisor support, Fringe benefits, teamwork, environment and training.

\section{INTRODUCTION}

$\mathrm{E}$ mployees' turnover appears to be rampant in manufacturing industry of the Tanzania due to de-motivational factors impacting employees' loyalty, resulting in employees seeking better opportunities in organizations within and outside the country. With the dearth of qualified personnel probably occasioned by the abundance of unemployable graduates, employee loyalty and retention become very important. Good employees ought to be retained and this may depend on their loyalty to the organization. This is as a result of many organizations trying to attract and recruit highly priced and competitive employees because they add value to their employers. To obtain employees' loyalty and retention so that they are not poached by competitors, there is the need for employers of labor to provide factors that motivate the employees to stay on.
Employee loyalty and retention are factor-based but there has been no agreement on the generally acceptable factors that motivate staff to be loyal and stay on the job.

(Uzma Hafeez, 2015 ) expresses that employees are the main asset of any organization and they are the main factors of organizational progress. Employee retention and loyalty is a challenge for HR manager especially in manufacturing industry of Tanzania which is a saturated market already in Tanzania. According to the National Bureau of Statistics (2016), many factors have led to some qualified personnel who possess the right knowledge, skills and abilities to leave Manufacturing industry and find greener opportunities in other lucrative sectors of the Tanzania' economy. Perhaps, longer working hours, increased workload, poor managerial style, job insecurity, poor working environment, insecurity with rewards and recognition, lack of work-life balance have been, lack of trainings, poor compensation and supervisory support are responsible for the incessant turnover in the sector.

This study aims to find the key factors that may affect the employees' loyalty towards the organization and extent to what they impact on loyalty and organizational commitment through regression equation. Factors that study selects for the construct are: Job Security, Supervisor support, Fringe benefits, teamwork, environment and training.

\section{LITERATURE REVIEW}

Employee commitment is the degree to which an employee identifies with the organization and wants to continue actively participating in it (Herat, 2013). Like a strong magnetic force attracting one metallic object to another, it is a measure of the employees $^{\text {ee }}$ willingness to remain with a firm in the future. It often reflects the employees ${ }^{e e}$ belief in the mission and goals of the firm, willingness to expend effort in their accomplishment, and intentions to continue working there. Commitment is usually stronger among longer-term employees, those who have experienced personal success in the organization, and those working with a committed employee group. According to Allen and Meyer (1990), employee commitment refers to the psychological attachment of workers to their workplace. Brian P. Niehoff, Robert H. Moorman, Gerald Blakely, Jack Fuller (2001) provided a useful outline of the work in the area of "Maintaining 
survivors' loyalty in a downsizing environment is a difficult problem for management practitioners". Carr (1939) investigated the relationship between loyalty to supervisor and employee's inrole and extra-role performance in comparison with that of organizational commitment in the People's Republic of China. His results indicated that loyalty to supervisor is positively related to job Security and intent to stay. Loyalty to supervisor explained variance in these two outcome variables over and above that explained by organizational commitment.

As per the literature syntheses it is said that this study intends to find the relationship of the factors affecting the loyalty of an employee in manufacturing industry of Tanzania and their commitment towards the organization they are currently working with.

\section{BACKGROUND}

Tanzania is an under developed country, striving hard for the economic and industrial growth, by choosing different alternatives and options. Recent crises of dollar appreciation in terms of shilling has left manufacturing industry a very few options of survival. In this critical condition many unseen strategic decision are made by the industries to survive which totally based on quality of information decision based on downsizing has led many employees to turnover because of lack of trust in organization and financial stability of the firm. Even many units have been shut down. These decision of turnover the sector or intent to leave is the impacts of de-motivational factors affecting on the employees' loyalty which has led to poor performance and commitment towards the strategic goals of organization.

Dunning (2000) explains that there are three factors that can influence employee loyalty to the company, namely: (a) personal attributes, such as individual age, gender, education, (b) organizational factors, such as organizational size and economic centralization, and (c) role related factors, such as workload and subordinate skills. I Ketut Andy Hermawan and I Gede Esha (2016) show that the method used is Principal Component Analysis (PCA) of 20 variables used and there are four factors that determine employee loyalty with a value of $74.45 \%$ which can explain all the variance in the data. Furthermore, the results of research conducted by Mishra, (1998) states that the motivation of work, compensation, career management, and job pressure had a significant positive effect on work loyalty. PT. Karya Swadaya Abadi (Karsa) is a transportation service company. Employee loyalty in this company is known to decrease. This is evident from the number of employees who leave the company to work in other companies. In 2013, there are 6 employees who moved to work in another company, in 2014 the number increased to 8 employees, Past studies depict bidirectional relationship between employee Security and job performance while recent studies give more insight of unidirectional relationship that employee Security leads to job performance but weak relationship exists when job Security was analyzed as a result of job performance (Bai, Sarkis, \& Dou, 2015), (Newell, 1958) and (Al-Zubi, 2015) concluded that employee Security and job performance are directly related and that job Security is the result of job performance. It is necessary for every organization to have full level of its employee commitment in order to have outstanding performance on long term basis (Simoens S, 2017). Currently employees act like entrepreneurs when they work in a team and every member of the team tries his level best to prove one the best amongst all others (Tian, 27 October 2015). Increase in commitment level of employees in organization ultimately increases the performance of their employees. In past organizations provide job security to its employees to improve their commitment level in the organization and to improve their productivity (Zhou, 2017). Higher level of organizational commitment in the organization for individual projects or to the business is assumed as a major reason for better employee performance that leads to organizational success. The employee performance can also be increased when the employees are more satisfied with their job and duties as well. Their Security may depend on the rewards system, the organizational culture and employee knowledge sharing (topalovic, 2014).

\section{THEORETICAL FRAMEWORK}

(topalovic, 2014) brought the term job satisfaction, to limelight, for this he reviewed thirty two studies and observed that it is a combination of environmental, physiological and psychological circumstances and the variables influencing the level of satisfaction of an individual. A number of features: attitudes towards pay, working conditions, co-workers and managers, career prospects and intrinsic aspects of the job may influence the level of employee's satisfaction in the organization. Job satisfaction therefore is a measurement of job and work expectations and not just an overall holistic attitudinal manifestation. The concept of job satisfaction is multifaceted hence a number of theories are advanced to explain what it means and how the theories could be applied to enhance employee performance. (Meyer, 1990) and (U, 2017) suggest that job satisfaction may be regarded as: a cluster of positive and negative dispositions which are acquired and learned through experience, positive or negative attitudes based upon a person's genetic inheritance, an outcome of an individual's construction of his or her workplace reality, experience and mutuality of colleagues and supervisor's evaluation, and an individual's job characteristics and the extent to which an individual attempts to fit in with these characteristics according to his requirements from a job. As earlier stated, job satisfaction at its most general conceptualization, is simply how content an individual is with his job. Simply stated, job satisfaction refers to the attributes and feelings people have about their work. Positive and favorable attitudes towards the job indicate job satisfaction. Negative and unfavorable attitudes towards the job indicate job dissatisfaction (Al-Zubi, 2015). This satisfaction may be affective: one-dimensional subjective construct representing an overall emotional feeling individuals have about their job as a whole (Zhenxiong Chen, 2001), (Yurimoto, 1995) and (Steers, 2015). Among the content theories of motivation, Herzberg (1959) theory emphasizing the motivatorhygiene factors sought to explain satisfaction and motivation in the organization. The theory focuses on outcomes of satisfaction and dissatisfaction. The theory further found that certain aspects of a job cause satisfaction and therefore motivation, but certain aspects caused job dissatisfaction. Herzberg explained that the factors that lead to satisfaction or to dissatisfaction are different. Accordingly, he states that 'the opposite of job satisfaction is not job dissatisfaction but, rather, no satisfaction; and the opposite of job dissatisfaction is not job satisfaction but no satisfaction' 
(Herzberg, 2003.91). This theory states that job satisfaction and dissatisfaction is a product of different factors - motivation and hygiene respectively. According to Thompson \& Phua (2001) the affective event theory was developed by Psychologist Howard M. Weiss and Russell Cropanzano to explain how emotions and moods influence job satisfaction. The theory explains the linkages between employees' internal influences - cognitions, emotions, mental states etc and their reactions to incidents that occur in their work environment that affect their performance, organizational commitment, and job satisfaction (Wegge, van Dick, Fisher, West \& Dawson, 2006). Equity theory, as reviewed by Walster, Berscheid \& Walster (1973) shows how a person perceives fairness in regard to social relationships. The theory presupposes that during a social exchange, a person identifies the amount of input gained from a relationship compared to the output, as well as how much effort another person's puts forth. Based on Adam (1965) theory, Huseman, Hatfield \& Miles (1987) further suggest that if an employee thinks there is an inequity between two social groups or individuals, the employee is likely to be distressed or dissatisfied because the input and the output are not equal. Inputs encompass the quality and quantity of the employee's contributions to his or her work. Job characteristic theory (Hackman \& Oldham 1976), Schermerhorn, Jr (1984), Hellriegel, Jackson \& Slocum (1999) and Dugguh (2008) propose a framework to study how particular job characteristics affect job outcomes and job satisfaction. The framework states that there are a number of core job characteristics that impact on job outcomes. According to Bernard, Mills, Swenson and Walsh (2005) motivation is theorized as a "purposeful behavior that is ultimately directed toward the fundamental goal of inclusive fitness" ( $p$. 129). Bernard et al., (2005) propose that due to the randomness of behaviors and interests, an individual's differences may be guided by motives. Based on this theory, the study will attempt to define what guiding factors or motives, employees use to motivate themselves and what impact if any it may have on the feelings of loyalty and commitment shown to one's employer. Every employee has differing motivational factors that can potentially impact their degree of loyalty and commitment. As such, I theorize that if an employee is satisfied with his or her work environment, then he or she will be loyal and committed to one's employer. Similarly, if an employee is motivated to achieve a goal, receive recognition, or has an expectation to receive a promotion, he or she in turn will also be loyal and committed to one's employer. As defined by Logan (1984) loyalty is "a strong tie that binds an employee to his [or her] company even when it may not be economically sound for him [or her] to stay there". Employees' Loyalty is "is a deliberate commitment to further the best interests of one's employer, even when doing so may demand sacrificing some aspect of one's self-interest beyond what would be required by one's legal and other moral duties" (Elegido, 2013, p. 496). Commitment according to Anderson and Weitz (1992) and Morgan and Hunt (1994), "is a long-term relational perspective [that] encourages parties to resist the short-term benefits offered by other [companies] in favor of the benefits associated with remaining in a relationship" (as cited in Dagger, David \& $\mathrm{Ng}$, 2011, p. 276). Employee Commitment has three levels. If an employee falls within the affective commitment level, they identify with and are emotionally attached to their organization so much so that they remain with the same employer because they want to (Pepe, 2010). If an employee falls within the continuance commitment level, they remain with the same employer for numerous years because they are aware of the expenses connected with leaving, so they choose to remain not because they want to, but because they need to (Pepe, 2010). Finally, if an employee exhibits normative commitment, they opt to stay with an organization, not because they want to, or because they have to but it's alternatively because they feel they ought to (Meyer \& Allen, 1991 as cited in Pepe, 2010). Motivation can be "defined as purposeful behavior that is ultimately directed toward [a] fundamental goal..." which "may be measured in terms of individual difference in covarying categories of behaviors and interest" (Bernard, Mills, Swenson \& Walsh, 2005, p. 129). Work Motivation "is the steering of human activity towards a desired objective by means of motives generated internally in a person or in his or her environment, on the basis of his or her needs" (Peklar \& Bostjancic, 2012, p. 57). Intrinsic Motivation "refers to a desire to work primarily because the work itself is interesting, challenging and satisfying to the person" (Cantania 2013). Extrinsic Motivation occurs when an employee "performs an activity with the intention of attaining some separable consequence, such as receiving an award, avoiding guilt, or gaining approval" (Deci, Ryan, \& Williams, 1996 as cited in Dysvik \& Kuvaas, 2013, p. 413).

\section{OBJECTIVES}

Objective of this study is to highlight the importance of motivational factors and employees' loyalty in manufacturing industry which is directly related to commitment of an employee towards the organization and performance of employees. Purpose of this study is to correlate the factors with loyalty and commitment. Seemingly in this critical conditions where Tanzania's economy and shilling value is smashed to the earth highly qualified and skill people are leaving country or switching their job for better jobs. In this situation employee retention on low wage or on low provided circumstances is not possible. This study keeping in view the situation intends to highlight the factors that can retain the employees if applied properly and with unbiased behaviors.

\section{Statement of Problem}

Study opts to answer few key questions regarding Loyalty and commitment of employees in manufacturing industry of Tanzania.

1. What is Employee Loyalty in manufacturing sectors and how does it effects the organizational commitment?

2. To what extent factors such as: Job Security, Supervisor support, Fringe benefits, teamwork, environment and training affect the employee loyalty and commitment? 
3. Is there any relationship between and within loyalty and commitment of an employee towards the organization?

4. Security level of employees towards the organization and their job given the factors affecting the loyalty of employees?

5. Innovative systematic strategies to retain the employees by increasing their loyalty and commitment

\section{Hypotheses:}

$\mathrm{H} 1_{0}$ : Employees' Loyalty in manufacturing industry of the Tanzania is directly proportional to the organization commitment and performance of the employees.

$\mathrm{H} 2_{0}$ : Job Security, Supervisor support, Fringe benefits, teamwork, environment and training do not affect the employees' Satisfaction level and do not affect employee loyalty and commitment towards organization in manufacturing industries of Tanzania.

Figure 1 Conceptual Diagram Based On Satisfaction Model

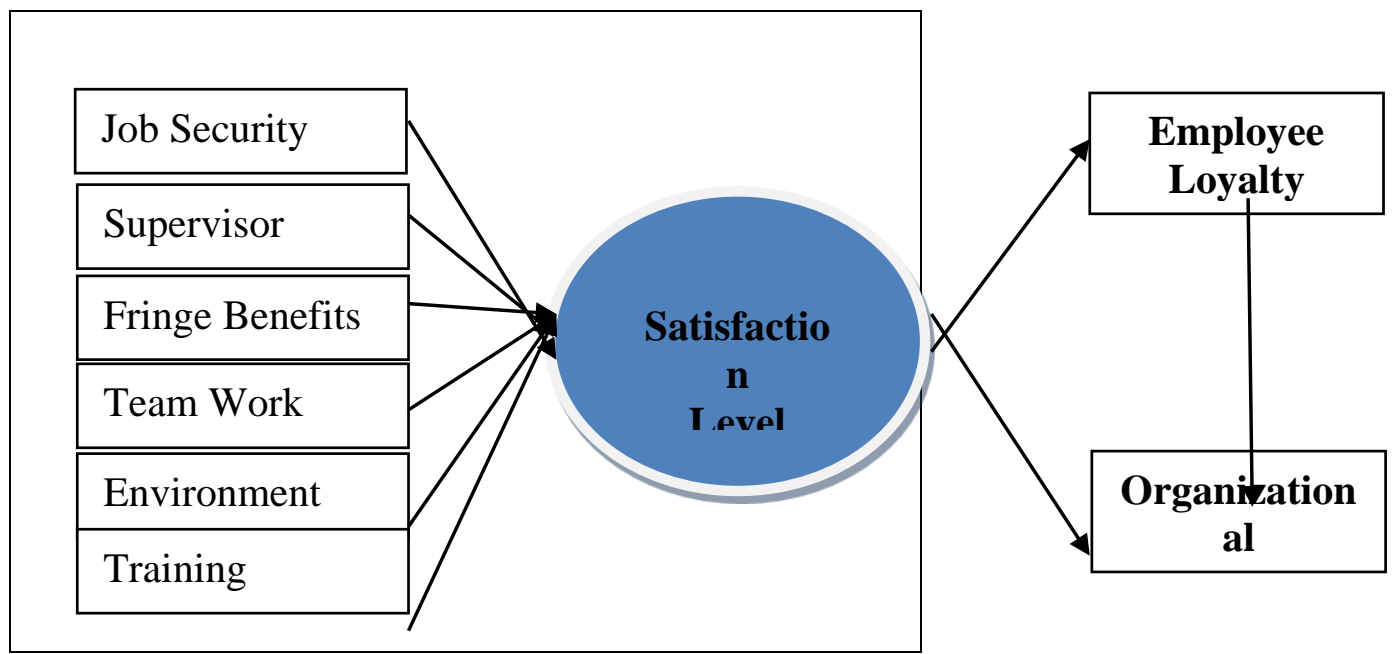

\section{RESEARCH DESIGN}

This is study is a quantitative approach to identify the correlation between dependent and independent variable, organizational Loyalty is dependent variable whereas Job Security, Supervisor support, Fringe benefits, teamwork, environment and training are the independent variables. Study uses survey questionnaire to collect data from manufacturing industry of Tanzania. Population of the study is categorized in the Low level employees, Middle level Employees and High level employees who are involved in organization at least for 2 years.

\section{DATA COLLECTION}

Data is collected through self-made five likert scale questionnaire from the manufacturing industry of Tanzania. All the categories of population are randomly selected through cluster sampling.

\begin{tabular}{lll}
\hline S/No. & Scale & Categories \\
\hline 1 & 0 to 1 & Strongly Disagree \\
2 & 1.1 to 2 & Disagree \\
3 & 2.1 to 3 & Neutral \\
4 & 3.1 to 4 & Agree \\
5 & 4.1 to 5 & Strongly Agree \\
\hline
\end{tabular}

Table 1 interpretation of Ratings in Questionnaire.

IX. SAMPLING

Population sampling is carried out by Slovin's formula of known sampling. Random selection is conducted through cluster based. Selected manufacturing factories employees from corporations of large scale and medium sized will be contacted for information gathering

Research Sample $=n=N /\left(1+N e^{2}\right)$

$N=1300 /(1+1300 * .07 * .07)$

$N=1300 / 7.37=176($ Sample Size $)$

\begin{tabular}{lllll}
\hline S/No. & Categories & Numbers & Percentage & Total \\
\hline 1 & Low Level & 31 & $7.19 \%$ & 350 \\
2 & Middle Level & 45 & $21.58 \%$ & 400 \\
3 & High Level & 90 & $64.08 \%$ & 550 \\
\hline Total & & 176 & $100 \%$ & 1300 \\
\hline
\end{tabular}


Source: Survey Data@2019 Manufacturing Industry,Tanzania

Table 2 Population and Sampling
Slovin's formula was applied to sample the participant size from the population (known) size, producing 176 sampled participant of the study (see table 2). Participants were randomly selected once the sample size was established from manufacturing corporations of Tanzania.

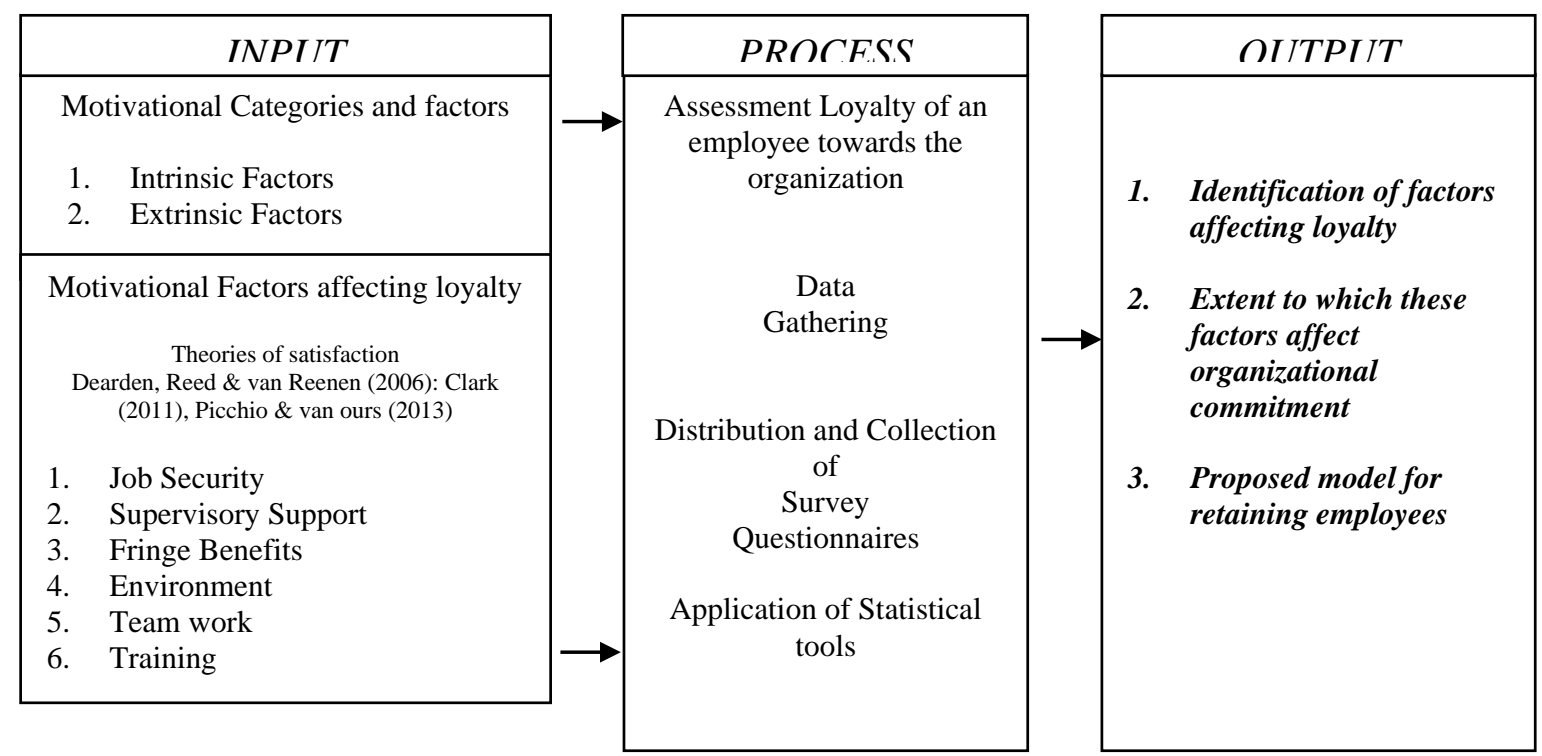

Figure 2 Research Paradigm based on Conceptual Framework

\section{INTERPRETATION \& ANALYSIS}

Reliability analysis:

Before collecting complete data from (176) participants', reliability test was conducted to authenticate the questionnaire. 20 recipients were selected from the sample and distributed the questionnaire for initial test, "Cronbach's Alpha" value for all 5 categories of the questionnaire surpassed .70 or $70 \%$ required percentage. Table 3 exhibits the values of Cronbach Alpha for volume, velocity, variety, veracity and value, which implies that categorically all the values of reliability test surpassed required results, hence questionnaire proved reliable for further process.

\begin{tabular}{llll}
\hline S/No. & Variables & $\begin{array}{c}\text { Cronbach's } \\
\text { Alpha }\end{array}$ & \% \\
\hline 1 & Job Security & 30.843 & $84.3 \%$ \\
2 & Supervisory Support & 30.789 & $78.9 \%$ \\
3 & Fringe Benefits & 30.913 & $91.3 \%$ \\
4 & Environment & 30.904 & $90.4 \%$ \\
5 & Team work & 30.872 & $87.2 \%$ \\
6 & Training & 30.901 & $90.1 \%$ \\
overall & & .911 & $91.1 \%$ \\
\hline
\end{tabular}

Table 3 Reliability Analysis Test

\section{Hypotheses Testing}

Null hypotheses were testes for $t$-values and $p$-values, in order to nullify the null hypotheses and accept study hypotheses. Independent sample test ( 2 tailed) applied for rejection of null hypotheses exhibited in table 4 . Table 4 exhibits $t$-values and $p$ - values of independent sample 2 tailed tests, $t_{\mathrm{js}}=2.4081, t_{\mathrm{ss}}=3.39$, $t_{\mathrm{fb}}=5.67, t_{\mathrm{e}}=2.99, t_{\mathrm{tw}}=6.34, \& t_{\mathrm{t}}=4.34$ all the values are greater than $t$-table values for degree of freedom @ 175. Values exhibited in table 4 imply that all null hypotheses of the study are rejected and study hypotheses are accepted. $P$-values exhibited in table 4 are less than .50 which implies model is significant different and fit for prediction.

\begin{tabular}{|c|c|c|c|c|c|c|}
\hline S/No. & Factors & numbers & $\begin{array}{l}\text { t-test } \\
\text { statistic }\end{array}$ & $\begin{array}{l}P \\
\text { Value }\end{array}$ & $\begin{array}{l}\text { t-table } \\
\text { value }\end{array}$ & \\
\hline 1 & Job Security & 6 & 2.4081 & .012 & $\begin{array}{l}>\mathrm{T} \\
\text { value }\end{array}$ & $\overline{\text { table }}$ \\
\hline 2 & $\begin{array}{l}\text { Supervisory } \\
\text { Support }\end{array}$ & 6 & 3.3932 & .000 & $\begin{array}{l}>\mathrm{T} \\
\text { value }\end{array}$ & table \\
\hline 3 & $\begin{array}{l}\text { Fringe } \\
\text { Benefits }\end{array}$ & 6 & 5.6723 & .013 & $\begin{array}{l}>\mathrm{T} \\
\text { value }\end{array}$ & table \\
\hline 4 & Environment & 6 & 2.9987 & .023 & $\begin{array}{l}>\mathrm{T} \\
\text { value }\end{array}$ & table \\
\hline 5 & Team work & 6 & 6.3456 & .000 & $\begin{array}{l}>\mathrm{T} \\
\text { value }\end{array}$ & table \\
\hline 6 & Training & 6 & 4.3456 & .000 & $\begin{array}{l}>\mathrm{T} \\
\text { value }\end{array}$ & table \\
\hline
\end{tabular}

Table 4 Hypotheses Testing (Independent Sample Test)

Results of the independent sample test ( 2 tailed) establishes argument that model is fit and null hypotheses of the study are rejected, qualitative expression for this narration is that factors mentioned in table 4 affect the loyalty of employees and commitment towards organizations in manufacturing industry of Tanzania though impact level of some of the characteristics are high and some are low. 


\section{Descriptive Statistics}

Interpretation of mean ratings of the summary from the participant of the study (Low level, Middle level and high level Employees) is covered in descriptive statistics section of the paper. Study used 5 likert scale ratings to record the ratings of the participant, sharing experienced based knowledge. Employees' commitment and loyalty are dependent on job Security, Supervisor Support, Fringe Benefits, Team Work, Environment and Training for better and efficient business mechanism and smooth running of affairs. Study covers the expert opinion of employees facing the situation on real grounds of Tanzanian Corporate sectors expressing the narration that improvement in factors (Independent) can affect the loyalty of employee in positive manner which may lead to perfect commitment with corporate as employee loyalty and commitment are positively correlated.

\begin{tabular}{|c|c|c|c|c|c|c|}
\hline \multirow{3}{*}{ Factors } & \multicolumn{2}{|c|}{ Executives } & \multicolumn{2}{|c|}{ Directors } & \multicolumn{2}{|c|}{ Managers } \\
\hline & Mea & Classif & Mea & Class & $\mathrm{oMe}$ & Classificatio \\
\hline & $\mathrm{n}$ & $\mathrm{n}$ & $\mathrm{n}$ & $\mathrm{n}$ & $\mathrm{n}$ & $\mathrm{n}$ \\
\hline $\begin{array}{l}\text { Job } \\
\text { Security }\end{array}$ & 3.9 & S.A & 4.2 & S.A & 3.1 & S.A \\
\hline $\begin{array}{l}\text { Supervisor } \\
\text { y Support }\end{array}$ & 4.4 & S.A & 4.1 & S.A & 3.7 & S.A \\
\hline $\begin{array}{l}\text { Fringe } \\
\text { Benefits }\end{array}$ & 4.2 & S.A & 4.2 & S.A & 3.2 & SA \\
\hline $\begin{array}{l}\text { Environme } \\
\mathrm{nt}\end{array}$ & 3.3 & S.A & 4.5 & S.A & 4.3 & S.A \\
\hline Team work & 4.1 & S.A & 4.1 & S.A & 3.5 & S.A \\
\hline
\end{tabular}

Table 5 comparison of mean ratings and classification

Table 5 exhibits value of mean ratings of low level employees, middle level employees and high level employees (Participants) on job Security, Supervisor Support, Fringe Benefits, Team Work, Environment and Training as independent factors and impacts of these 5 factors on Employee Loyalty and Job Commitment of corporate indexed on Dar es Salaam stock exchange of Tanzania. Values of table 6 imply that all the participants are either agreed or strongly agreed with the statements of the questionnaire level employees and high level employees (Participants) are the employees, measured for the employee loyalty with corporate and extent of commitment with organization. Qualitatively expressed their opinion, in manufacturing industry of Tanzania that issues related to the job Security, Supervisor Support, Fringe Benefits, Team Work, Environment and Training can lead a positively or negatively affect the employee working in corporate, I handled properly these factors can work magically well for corporate else they may result in worst conditions for corporate of the Tanzania.

Normally, Satisfaction model is applied for the measurement of the factors associating with behavioral and attitudinal impacts of employee working so this study follows the conceptual model of satisfaction and measure the level of satisfaction of Tanzanian corporate sector employees with job Security, Supervisor Support, Fringe Benefits, Team Work, Environment and Training provided in the firm they employed with for over 2 years.

\section{Regression Analysis}

The linear regression was developed to investigate how one or more independent variables influence a dependent variable (Hutchinson, 2011). More specifically, in a linear regression analysis, the result produces one intercept and one slope, based on the mean, which represents the best fit for variable $X$ to predict variable $\mathrm{Y}$. The regression line can be calculated by using the equation (Noon, 2003): This study uses job Security, Supervisor Support, Fringe Benefits, Team Work, Environment and Training factors affecting the employee, as independent variable and loyalty and commitment of an employee as dependent variable.

\begin{tabular}{lllll}
\hline MODEL & $\boldsymbol{R}$ & R Square & $\begin{array}{l}\text { Adjusted } \\
\text { Square }\end{array}$ & $\begin{array}{c}\text { RStd. Error of } \\
\text { the Estimate }\end{array}$ \\
\hline $\mathbf{1}$ & $.912^{\mathrm{a}}$ & .900 & .900 & .0435 \\
\hline
\end{tabular}

Table 6 Regression Model Summary

Adjusted R square of the model is .900 that means $.900 * 100=$ $90 \%$. It implies that $100 \%$ of change in job Security, Supervisor Support, Fringe Benefits, Team Work, Environment and Training (+ve or -Ve) will bring $90 \%$ change Loyalty of an employee towards organization and will correlate the commitment of an employee for the measurement with corporate of Tanzania. It also implies that model is highly predictable to dependant variable. Predictor is constant with R-square $90 \%$. Corporation efficiency is effectively and efficiently increases to $90 \%$, affected by job Security, Supervisor Support, Fringe Benefits, Team Work, Environment and Training, thus sector needs to focus on the these factors as linear functionality.

\begin{tabular}{c} 
CHANGE STATISTICS \\
$\begin{array}{c}\text { MODELR Square } \\
\text { change }\end{array}$ F-Change Df1 Df2 $\begin{array}{l}\text { Sig. F } \\
\text { Change }\end{array}$ \\
\hline
\end{tabular}

\begin{tabular}{llllll}
\hline 1 & .900 & 22.776 & 3 & 173 & .123 \\
\hline
\end{tabular}

Data source: survey data dated: October, 2019 @ manufacturing industry, labor zone Karachi industries

Table 7 change statistics of model

Table 7 explains R-Change is the same in change statistics as was in the summary model table 6 , with $\mathrm{f}(3,173)=22.776$, $p=.123$ model is significant and will bring change for sure as $P<$ .05 , it can be predict that model is significant and will bring changes in decision making efficiency of corporation for sure with the changes in all the independent variables. It implies that $\%$ job Security, Supervisor Support, Fringe Benefits, Team Work, Environment and Training Value will bring \% change in corporate sectors loyalty of employees and commitment that influences the overall performance of the corporate as a team. Corporate sectors 
of manufacturing industry have integrated working mechanism all departments are interconnected with each other stitching is connected with production washing in is connection with operations $R \& D$ is connected with sales and marketing. Interrelated modules of manufacturing industry depend on each other for the performance improvement, connection of employee with the corporate needs to be standard and formulated for corporate as a single unit that will bring overall performance up. For the purpose managers, executive and directors need to provide job Security, Supervisor Support, Fringe Benefits, Team Work, Environment and Training same to all the employees with professional approach without biasness.

\begin{tabular}{lllllll}
\hline \multirow{2}{*}{ MODEL } & $\begin{array}{l}\text { Sum } \\
\text { Squares }\end{array}$ & $\boldsymbol{o f}_{\boldsymbol{D f}}$ & $\begin{array}{l}\text { Mean } \\
\text { Square }\end{array}$ & $\boldsymbol{F}$ & \multirow{2}{*}{ Sig. } \\
\hline \multirow{3}{*}{$\mathbf{1}$} & Regression & 32.124 & 3 & 22.113 & 22.776 & $.123^{\mathrm{b}}$ \\
& Residual & .234 & 173 & .004 & & \\
& Total & 32.358 & 173 & & & \\
\hline
\end{tabular}

Table 8 Analysis of variance for decision making of manufacturing industry

Table 8 implies the analysis of variance in model. $\sum\left(\mathrm{Y}_{1^{-}}\right.$ $Y)^{2}=32.124$ for the mean difference square of predicted value of D.V and I.V and $\mathrm{f}(3,173)=22.113, p=.123$, implies that model 1 of ANOVA is significantly fit to predict values and explain variation in factors. Qualitative expression for this variance implies that it can be predicted that job Security, Supervisor Support, Fringe Benefits, Team Work, Environment and Training (+ve or $-\mathrm{Ve})$ will affect the information employees loyalty to extent that they will be more committed to individual and whole goal of the corporate and that increases the performance as team. Organizations having less committed and loyal employees can get short run benefits but for longer run demand and supply curve decreases.

\begin{tabular}{ll|ll|l|l|l}
\hline \multirow{2}{*}{ MODEL } & \multicolumn{2}{|l|}{$\begin{array}{l}\text { Unstandardized } \\
\text { Coefficient }\end{array}$} & $\begin{array}{l}\text { Mean } \\
\text { Square }\end{array}$ & $\boldsymbol{F}$ & Sig. \\
& & $\boldsymbol{B}$ & Error & & \\
\hline $\mathbf{1}$ & .456 & .000 & & 2.536 & .123 \\
& (Constant) & 2.345 & .000 & 2.037 & 233.516 & .000 \\
Job Security & 3.233 & .010 & 2.172 & 38.731 & .000 \\
Supervisory & 1.234 & .123 & 4.232 & 56.345 & .231 \\
Support & 6.785 & .342 & 3.234 & 32.124 & .032 \\
Fringe Benefits & 4.235 & .101 & 1.345 & 1.223 & .431 \\
Environment & 3.214 & .345 & 1.345 & 4.234 & .142 \\
\hline
\end{tabular}

Table 9 Regression analysis

Table 9 exhibits@ $@=.123, .000, .000, .231, .032, .431$ and .142 all the values are less than .005 model is fit and significant to predict the effect of independent variable on dependent variable. With coefficients @ 2.345, 3.233, 1.234, 6.785, 4.235 and 3.214 Job Security, Supervisor Support, Fringe Benefits, Team Work, Environment and Training, linear model of regression predicts the degree change in independent variable with coefficients will increase the loyalty and commitment of employee. Linear model exhibits the values that imply research hypotheses are true and characteristics factors associated in corporate sector of Tanzania affect the targeted loyalty and commitment of employee in satisfaction model.

Loyalty Measurement $=\alpha+\beta(J S)+\beta(S S)+\beta(F B)+\beta(E n)+$ $\beta(T W)+\beta(T N)+e$

$L \_M=.456+2.345(J S)+3.233(S S)+1.234(F B)+6.785(E n)$ $+4.235(T W)+3.214(T N)+.05$

Employee Loyalty function is linear in nature, with a constant change unit of .456 (Constantly will change @ 45.6\% without the impact of factors) in measurement of corporate loyalty measurement scale Job Security, Supervisor Support, Fringe Benefits, Team Work, Environment and Training associating with Loyalty of Employee as constant changing variable. Tanzanian manufacturing industry is in capacity of providing better options for the employees of the firm, affects of factors in corporate sector to measure the ratings of Job Security, Supervisor Support, Fringe Benefits, Team Work, Environment and Training is provided with the related coefficient. All the coefficients are positive and related with each other that imply positive regression functionality. 


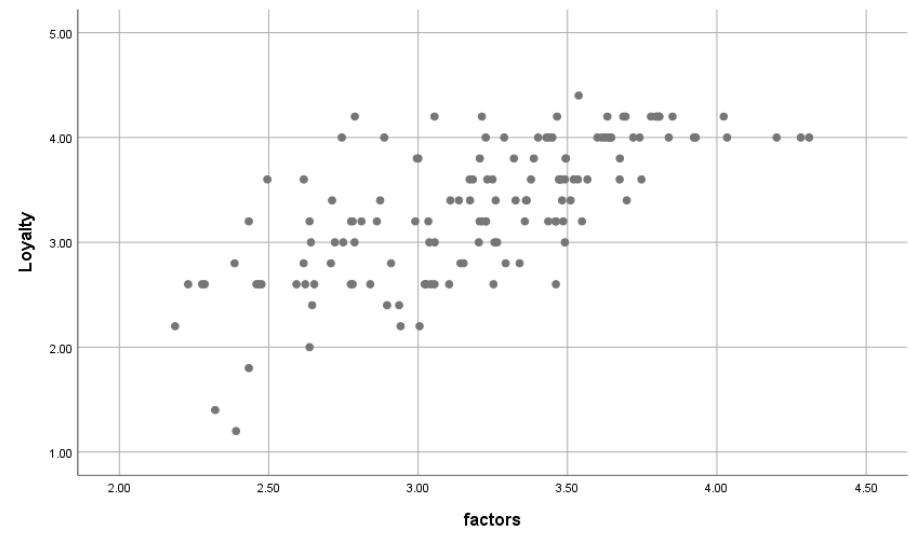

Figure 3 Curve fit Scatter plot for Loyalty of Employee

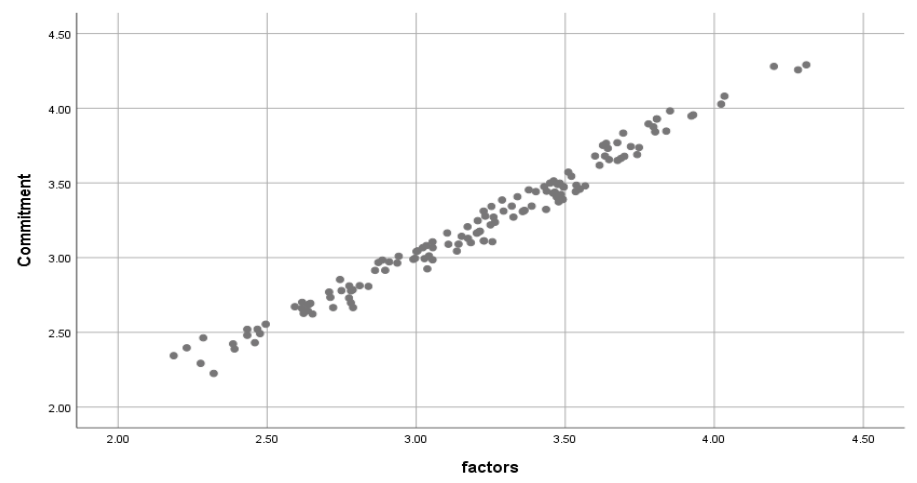

Figure 4 Curve fit Scatter plot for Commitment of Employee

\section{Correlation Analysis}

A correlation coefficient is a numerical measure of some type of correlation, meaning a statistical relationship between two variables. The variables may be two columns of a given data set of observations, often called a sample, or two components of a multivariate random variable with a known distribution. Linear function of loyalty of employee is directly related to Job Security, Supervisor Support, Fringe Benefits, Team Work, Environment and Training and significantly related to commitment of an employee towards corporate in manufacturing and services sectors. Ages of management has learnt that employees not treated will can be dangerous and harmful for corporate infrastructure and managerial impacts. Tanzania is a land where not much high skilled management like European countries is expected, but management tiers are applied for improvement and capacity buildup. Study shows that Job Security, Supervisor Support, Fringe Benefits, Team Work, Environment and Training have extent high impact on loyalty and commitment directly or indirectly, which corporate and manufacturing sector can use in benefit of organizational goals.

\begin{tabular}{llll}
\hline Items & Description & $\begin{array}{l}\text { Employee } \\
\text { Loyalty }\end{array}$ & $\begin{array}{l}\text { Organizational } \\
\text { Commitment }\end{array}$ \\
\hline Pearson Correlation & & \\
\hline Employee & Correlation & 1 & $.718^{* *}$ \\
Loyalty & Coefficient & & .123 \\
& Sig. (2-tailed) & 176 & 100 \\
\hline
\end{tabular}

\begin{tabular}{|c|c|c|c|}
\hline \multicolumn{2}{|c|}{$\begin{array}{r}\text { Correlation } \\
\text { OrganizationalCoefficient }\end{array}$} & $\begin{array}{l}.718^{* * *} \\
.123 \\
176\end{array}$ & 100 \\
\hline \multicolumn{4}{|c|}{ Non Parametric Kendall's tau_b } \\
\hline \multirow{3}{*}{$\begin{array}{l}\text { Employee } \\
\text { Loyalty }\end{array}$} & $\begin{array}{l}\text { Correlation } \\
\text { Coefficient }\end{array}$ & 1 & $.560^{* *}$ \\
\hline & Sig. (2-tailed) & & .000 \\
\hline & $\mathrm{N}$ & 176 & 100 \\
\hline \multirow{3}{*}{$\begin{array}{l}\text { Organizationa } \\
\text { Commitment }\end{array}$} & $\begin{array}{l}\text { Correlation } \\
l \text { Coefficient }\end{array}$ & $.560^{* *}$ & 1 \\
\hline & Sig. (2-tailed) & .000 & \\
\hline & $\mathrm{N}$ & 176 & 100 \\
\hline
\end{tabular}

Table 10 Correlation Matrix of Employee Loyalty and Organizational Commitment

Table 10 exhibits the Pearson correlation between Loyalty of an employee with firm and organizational commitment of employee in manufacturing industry of Tanzania, both the variables are positively correlated with each other at 0.718 (Pearson) with $\mathrm{N}=$ 176 and .560 (Kendall's tau_b) $\mathrm{N}=176$. Table 10 implies that there is a positive correlation with strong bonding. Positive usage and change in Loyalty of en employee will bring more commitment within the employee attitude and behavior for the organization and thus will ultimately be fruitful for Tanzanian corporate and manufacturing sector.

\section{LIMITATIONS OF THE STUDY:}

This study will examine how intrinsic and extrinsic motivational factors impact employee loyalty and commitment. Although the study does not examine external economic factors or personal situational influences that may impact an employee's decision to stay or quit, this study will however draw on results on self-made questionnaire to reveal what attributes describe an employee committed and loyal to one's employer and what if anything should an employer expect from the average employee who is loyal and committed. Participation in this study is restricted to employees who are above 18 years of age to 40 years, has previous or current work experience with the same employer for two (2) years at least, and who are willing to voluntarily participate. Individuals can be currently working or currently retired. If individuals do not meet the aforementioned criteria, they will be excluded from the study. Due to potential time constraints and the limited sample in which participants will be found, there is a possibility that the size of my sample may not amount to or be greater than 176 participants. Simply put, due to the time constraints and budget constraints only one city will be covered for data collection.

Another limitation of the study is that, this study does not cover the aspects of one's family issues related to turnover and switch for better job. Study does not provide any suitable suggested innovative work model for retaining the employees by increasing their loyalty and commitment towards the organization.

\section{SUMMARY OF FINDINGS:}


1. Job Security, Supervisor Support, Fringe Benefits, Team Work, Environment and Training are six main factors (Independent) associated with employee loyalty

2. All, Job Security, Supervisor Support, Fringe Benefits, Team Work, Environment and Training factors are inter-related with each other.

3. Job Security, Supervisor Support, Fringe Benefits, Team Work, Environment and Training are linear in function.

4. Job Security, Supervisor Support, Fringe Benefits, Team Work, Environment and Training are directly and significantly related with loyalty and commitment

5. There is a significant relationship between loyalty and commitment

6. Research Hypotheses are accepted and null hypotheses are rejected for the manufacturing industry of Tanzania.

\section{CONCLUSION}

Managerial skills required for managing such a corporate sector in heavily saturated market is unavailable and research based investigative business with empirical approach is hard to find in Tanzanian manufacturing and services sectors. Tanzania is less developed than European countries and having less literacy rate than many of the organizations does not provide any managerial leverage for measuring and sensing efficient output. Most the people involved are with low educational background in manufacturing industry. Foreign agencies and firms have firm footed routes in Tanzania, especially in capital city Dar es Salaam. Tanzania is rich in chemical and natural resources, exploration of heavy dearth can lead to a good GDP jump which lack at government level.

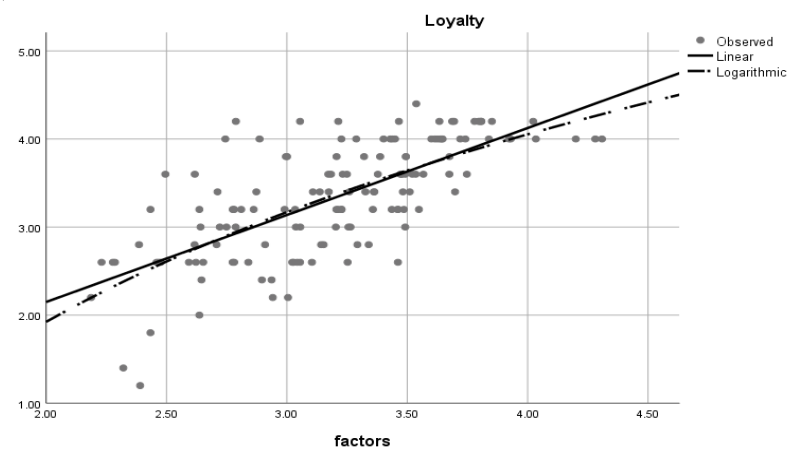

Figure 5 Linear regressions of Loyalty and factors

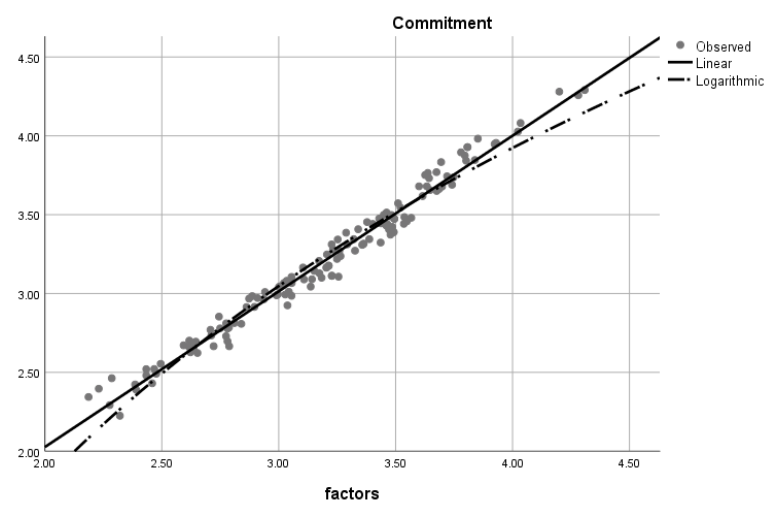

Figure 6 Linear regressions of commitment and factors

Study concludes few lines of investigation suggesting that Tanzanian business portfolios are run with less efficient management of human resource that is one reason of failure. Employee loyalty and commitment of employees to the organizations is ultimate goal of firms to achieve but with understanding the factors affecting the loyalty and commitment this argument remain in depth and not useful. Factors that study finds are Job Security, Supervisor Support, Fringe Benefits, Team Work, Environment and Training that affect the E.L and O.C in any organization and can change the fate of corporate.

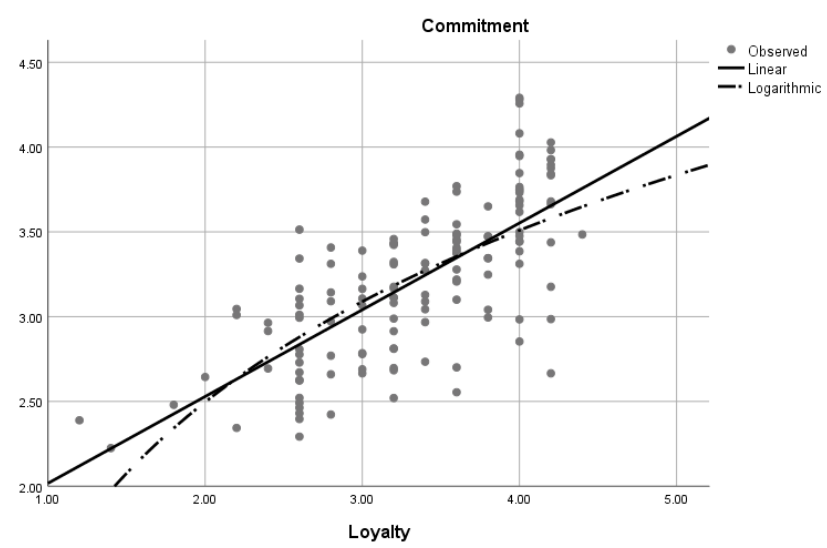

Figure 7 linear regressions of Loyalty and Commitment

Linear functionality of the loyalty and commitment can affect the performance of firm in many orders. Both are correlated with positive attributes and are interlinked with each other, study confirms the causal relationship and significantly different models to predict the impact factor of Job Security, Supervisor Support, Fringe Benefits, Team Work, Environment and Training on loyalty and commitment. Some applications for the conclusion can been seen as of in manufacturing industry of Tanzania; Textile and Clothing and chemicals industry where employees recently observed are leaving the firm and are not loyal to organization due to the influencing factors such as: Team work is less and senior member are not helping new entrants, Fringe benefits are less for skilled labour who are core working human capital of both the industry, supervisors' support is observed less due to less involvement and motivation towards work and Fringe benefits for additional hours working and spouses benefits are not motivating. All of this resulted in negative behavior in employees that 
threatens overall goals of strategic management. This research will provide awareness in managerial implications of the decisions regarding the employee and satisfying the needs to gain higher attention in distributive work. This research concludes, integration of work team at all levels is important not only to retain employees within organizations but also to attract new team members by sending positive gesture about corporations in manufacturing industry o Tanzania.

\section{REFERENCES}

[1] Al-Zubi, D. Z. (2015). The Effect of New Technological Changes In Improving.

[2] Bai, C., Sarkis, J., \& Dou, Y. (2015). Corporate sustainability development in China: review and analysis. Industrial Management \& Data Systems; Wembley .

[3] Binzel, C. A. (2011). "Egyptian Men Working Abroad: Labour-Supply Responses by the Women Left Behind.”. Labour Economics 18 (Suppl. 1), 98-114.

[4] Brian P. Niehoff, R. H. (2001). The Influence of Empowerment and Job Enrichment on Employee Loyalty in a Downsizing Environment. SAGE Journals , pp. 15-13.

[5] Carr, E. (1939). An introduction to the study of internaitonal relationship. London Macmillan .

[6] Dunning, J. H. (2000). "The Eclectic Paradigm as an Envelop for Economic and Business Theories of MNE Activities". Journal of International Business Review , 163-190.

[7] Esha, B. H. (2016). Consumer Buying Behavior towards Online Shopping: An Empirical Study on Dhaka City, Bangladesh. Cogent Business and Management, pp-23.

[8] Hamed, W. B. (2013). An empirical investigation of downsizing: A study of banking sector of Pakistan. African Journal of Business Management , 16401647.

[9] Herat, M. B. (2013). To Promote Employees Commitment via Perceived Organizational Support. International Journal of Academic Research in Business and Social Sciences, pp. 23-25.

[10] Jeffrey, K. (2011). Organisational downsizing and its impact on leavers and survivors: The case of the reserve bank of Zimbabwe. . Journal of Emerging Trends in Economics \& Management Sciences, , 264 - 269.

[11] Liu, X. a. (2007). "The Economic Pay-Offs to Informal Training: Evidence from Routine Service Work.” . Industrial and Labor Relations Review , 61 (1): 75-89.

[12] Meyer, A. a. (1990). The measurement and antecedents of affective, continuance and normative commitment to the organization. Journal of Occupational Psychology , pp. 12-15.

[13] Mishra, A. K. (1998). Explaining how survivors respond to downsizing: The role of trust, empowerment, justice, and work redesign. . Academy of Management Review, , 567-588.
[14] Mueller, P. a. (1981). Predictors of Organizational Commitment. HRM Reviews , pp 12.

[15] Newell, A. S. (1958). Elements of a theory of human problem solving. Psychological Review , pp. 155-166.

[16] Sahdev, K. (2003). Survivors' reactions to downsizing: The importance of contextual factors. Human Resources Management Journal, , 56-74.

[17] Salt, J. (2013). A comparative overview of international trends and types: 1950-80. International Migration Review, , 23, 431-456.

[18] Simoens S, S. A. (2017). Job satisfaction, work-related stress and intentions to quit of Scottish GPS. . Scott Med J. , pp 15.

[19] Simon, H. (1961). Does SCM affect Business Image and efficieny of Production . Technology Review , pp. 63-64.

[20] Steers, P. a. (2015). Consequences of Organizational Commitment . HR reviews and management, pp 28.

[21] Tian, B. (27 October 2015). Dynamical Trust and Reputation Computation Model for.topalovic, S. (2014). implementation of total quality managment . science direct .

[22] U, F. (2017). Job satisfaction, job stress and nurses' turnover intentions: The moderating roles of on-the-job and off-the-job embeddedness. National Medicine Reviw , pp .12.

[23] Uzma Hafeez, W. A. (2015 ). "Impact of Training on Employees Performance" (Evidence from Pharmaceutical Companies in Karachi, Pakistan). Business Management and Strategy , pp. 12-13.

[24] Wyborn, C. /. (2015). Situating Adaptation: How Governance Challenges and Perceptions of Uncertainty Influence Adaptation in the Rocky Mountains. Regional Environmental Change, 669682.

[25] Yurimoto, S. \&. (1995). "Design of a Decision Support System for Overseas Plant Location in the EC". Int. J. Production Economics , 411-418.

[26] Zhang, H. (2013). An E-Commerce Key Success Factors Framework for Chinese SME. Vol. 6.

[27] Zhenxiong Chen, A. s.-L. (2001). Employee Loyalty towards Organization A study of Academician. International Journal of Business and economics management, pp. 22-23.

[28] Zhou, L. D. (2017). Online Shopping Acceptance Model - A Critical Survey of Consumer Factors in Online Shopping. International Journal of Consumers Online Shopping , 8 (1), pp-14.

\section{AUTHORS}

First Author - Baraka Mboka Mwaitinda, School of Management Science \& MBA, North China University of water resources and electric power, Henan, China,

Mbokabaraka34@gmail.com

Second Author - Pei Feng Hu, School of Management Science \& MBA, North China University of water resources and electric power, Henan, China, pfhu04@163.com 